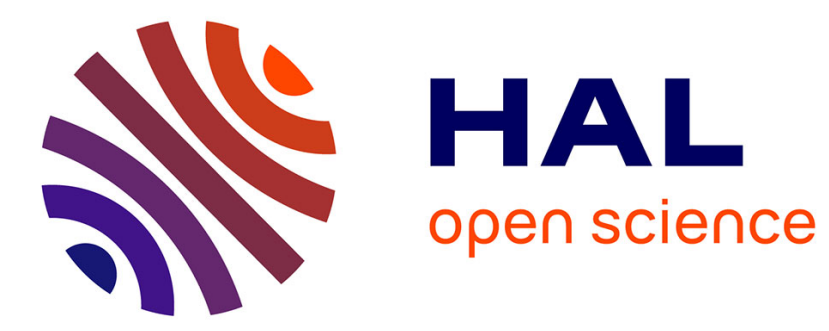

\title{
Courts of Law and Legal Practice
}

Daniela Berti

\section{To cite this version:}

Daniela Berti. Courts of Law and Legal Practice. A Companion to the Anthropology of India, 2011. halshs-02335114

\section{HAL Id: halshs-02335114 https://shs.hal.science/halshs-02335114}

Submitted on 28 Oct 2019

HAL is a multi-disciplinary open access archive for the deposit and dissemination of scientific research documents, whether they are published or not. The documents may come from teaching and research institutions in France or abroad, or from public or private research centers.
L'archive ouverte pluridisciplinaire HAL, est destinée au dépôt et à la diffusion de documents scientifiques de niveau recherche, publiés ou non, émanant des établissements d'enseignement et de recherche français ou étrangers, des laboratoires publics ou privés. 
[Published in Isabelle Clark-Decès, ed., A Companion to the Anthropology of India. Chichester: Wiley-Blackwell, 2011, pp. 355-70]

[Chapter 19]

Courts of Law and Legal Practice

DANIELA BERTI

$/ p .365 /$

INTRODUCTION

Although law courts in India still carry characteristics of their colonial origin, judicial concepts and court proceedings have evolved so as to adapt to the specificity of Indian society and its many other judiciary systems. In these legal settings, where hierarchy and codes of behavior are based on official roles and bureaucratic formalities, one may observe the interactions between state power and local society at work in routine practice throughout the country, even in the smallest towns and district headquarters. For the most part, however, anthropologists have neglected the study of these institutions, which has been largely taken up by jurists, lawyers and legal experts. As a result, most of the work on the judiciary in India is more concerned with the normative judicial system than with the practice of law itself. When social scientists discuss the professional services of lawyers, prosecutors, judges - for example, how lawyers give legal advice and represent clients in legal negotiation - and courts proceedings such as law suits court, it is often to denounce some malfunction or to propose solutions.

The neglect by anthropologists of judiciary practice in India is even more regrettable as soon as we realize that courts of justice provide windows onto significant facets of Indian society (Galanter 1992b:3). The numerous cases daily registered in various courts, including trial or appeal courts, pertain to a wide range of social issues - family disputes over marriage or hereditary rights, caste discrimination, criminal matters of various kinds - and in the case of the higher courts, issues concerning religious institutions, environmental matters, and fundamental constitutional rights. Court cases, therefore, are critical entry points for studying not merely rules of adjudication and the processes by which disputes are resolved and norms are elaborated, but also the workings of society from the vantage point of litigation and arbitration.

\section{/p.356/}

\section{SOME APPROACHES TO LAW AND THE JUDICIARY IN INDIA}

During the 1950s and 1960s legal scholars working in India found the roots of Indian "traditional" law in Sanskrit-based Hindu law, Islamic legal systems, "customary" law prevailing at the local level, and the interactions between this multi-tiered system and state law. Viewing custom as an extremely flexible source of law that constantly adapts to the requirements of official law, such scholars condemned approaches that treated custom as a body of ancient and stable practices that could be ascertained and codified, rather than as socially contingent processes amenable to change (Derrett 1957; 1968; Lingat 1973; Kane 
1950). Werner Menski (2003), for example, maintained that custom continued to be the preferential source of law, both de facto in the everyday practice of justice and more formally in specific legal cases. Richard P. Lariviere (2005) and Menski went on to criticize the colonial equation of the classical texts of Hinduism with positive law (see also Davis 2007).

In the mid-twentieth century anthropologists working in India began using ethnographic methods in order to underline the tactical possibilities offered by legal plurality. The precursor of these "field oriented" studies was M. N. Srinivas (1964), who recorded detailed reports of village disputes and villagers" practical use of "indigenous" and official law. Building on Srinivas's concept of "bi-legality," Bernard Cohn (1987a; 1987b) went on to underscore the importance of analyzing the reasons that led villagers to choose one legal system over another and the consequences of these decisions on village relationships. Aware that the introduction of a Western legal system in India had produced a "direct clash of values of two societies," Cohn emphasized villagers' use of the court to lodge phony cases against enemies (Cohn 1987b:569). He even compared court proceedings to a form of gambling, a sort of "slot machine" as the historian Percival Spear had once put it, that offered villagers the opportunity to win cases that they could not have won in the village legal setting (Cohn 1987a:90). Similarly, Marc Galanter, an American sociologist with a legal background, put forward what he called a "forum shopping attitude" between two sets of norms - the "lawyer's law" and the "local law-ways" (Galanter 1968-9). Galanter's works on the Indian legal system touched upon a wide range of legal issues, including India's reservation policies or "compensatory discrimination" (1984), for which he provided a detailed account of judicial doctrine and its social consequences (Deva 2005). In many of his works, he emphasized the disparity between law on paper and law in action, as in the case of the abolition of untouchability (Galanter and Khosla 1987), and the relationship between official regulation and nongovernmental controls of social life, especially in the emergence of distinctively modern legal institutions. These themes also surfaced in his study of Nyaya Panchayat - village courts created by the state in rural areas for "further displacing traditional local law by official law within the village" (Galanter 1992a; see also Galanter and Baxi 1979).

Toward the end of the 1960s, Galanter coordinated a special issue of Law and Society Review devoted to the study of Indian legal professions and based on microlevel, localized fieldwork. In the introduction to the issue, the editor explained that the volume specifically focused on the figure of the lawyer - an intermediary figure who disseminates official norms by "putting the law in the service of a wide variety of groups in the society" (Galanter 1968-9:202). Subsequently, Livia Holden /p.357/ (2003; 2008) revisited the pivotal role of the lawyer in mediating between the discourses of custom and those of official law in cases of Hindu divorce in the state of Madhya Pradesh. Her argument that lawyers manage the delicate task "not only of translating custom into law but also of translating law into custom for the benefit of their clients" (Holden 2008:160) underscored how the growing awareness of official law, even at the village level, changes the way custom is perceived and presented before official jurisdictions (Holden 2008). 1

Most studies of the anthropology and history of law and justice in India, then, operate within the framework of legal pluralism, that is they take it for granted that multiple legal systems coexist in Indian society. 2 In the 1990s, however, Michael R. Anderson (1990) critically questioned the importance given to legal pluralism and the contradictions and oppositions between an "alien" state versus an "indigenous" custom. Anchoring his discussion in recent Indian medieval historiography, Anderson argued that a centralized political power and local dynamics of loyalty and authority already existed in precolonial times, specifically during Mughal rule. Thus conflicts between village and other law regimes could not be simply the inevitable by-product of the colonial encounter. Anderson also 
underscored the importance of understanding "how the structural distribution of political authority is related to processes of production and social reproduction" (1990:163) - a perspective that was further developed by Radhika Singha (1998), Sandria B. Freitag (1991), and Anindita Mukhopadhyay (2006) who analyzed justice and the subject of law not in terms of legal juxtaposition and hybridity but in relation to historical transformations in administrative and political contexts.

Aside from the social science literature on Indian justice, numerous Indian jurists and university professors of law regularly publish material in specialized journals devoted to Indian legal studies. Most of these publications pertain to legal texts and the interpretation of statutes and court judgments from a legal point of view (Anderson 1990). Increasingly, though, their authors refer to social theory and make the case for legal reforms, exploring, for example, the social, political and sociolegal implications of legal texts, judges' decisions and other judiciary reports in order to denounce social injustices or suggest ways of improving a dysfunctional court system. This commitment to sociolegal activism tends to blur the distinction between jurists and committed social scientists - as can be seen, for instance, in the ongoing debates concerning a unified civil code, the reservations policy, gender inequality, human rights, or environmental protection (Sathe 2002; Noorani 2002). Upendra Baxi (1982) has compiled a set of essays that review these debates and analyze the causes of what he calls "the crisis of the Indian legal system" (see also Agnes 1999; Larson 2001; Dhagamwar 2006; Menski 1998).

This quick survey of the literature on the judiciary in India suggests that scholars have been concerned with the content of the law and the functionality of the legal system in Indian society. Although some anthropologists have approached these judicial settings from an ethnographic perspective, their observations have remained rather general, neither specifying the ways in which specific courts deal with cases on a daily basis, nor the processes by which cases are constructed and defended by both plaintiffs and defendants. The following sections of this chapter propose a more rounded ethnographic approach to the study of legal issues, calling for extended fieldwork in order to study the judiciary at the very place of its daily practice. My discussion /p.358/ pertains to Indian state courts, and not village-level institutions, such as village or caste panchayat (councils),3 or informal state systems of arbitration.

\section{ETHNOGRAPHY OF COURTROOMS}

In the 1970s, ethnomethodologists and conversation analysts began to study US and European law courts as social institutions in which power-laden interactions between differently positioned actors come sharply into play. They call for greater attention to the tools of linguistics in order to better appreciate the importance of language in legal processes and court interactions, including the conversational mechanisms behind courtroom talk and the strategies used by protagonists to turn situations to their own advantage (Atkinson and Drew 1979; Conley and O'Barr 1990; Drew and Heritage 1992; Gnisci and Pontecorvo 2004). Recently, anthropologists working in non-Western countries have adopted this method (Chang 2004; Richland 2008; Dupret 2006; Stiles 2009), to the exception of those working in India where there is very little work done on courtrooms, and this despite the fact that ethnographers there do study the clash between courts and village institutions of dispute settlement. My argument is that the study of court interactions during a trial provides substantial insight into the ways in which Indian judiciary proceedings are concretely acted out, as well as the processes by which courtroom power relations influence legal outcomes. Such study also highlights some of the ways in which state power is concretely implemented 
in contemporary India. This is especially true in the study of trial courts, where judges and other officers are regularly involved in both direct interactions with ordinary people and the meticulous collecting and recording of facts. Indeed, trial courts function as places where social facts have to be registered and judged under one or more sections of the Indian legal code and where individual narrations of these facts are shaped by a specific question-and-answer form that follows specific rules and legal constraints. Thus any ethnography of court cases needs to take into account not only the reports provided by courts, but also the ways in which these documents are produced in the first place. Based on the court interactions I observed in 2006 and 2007 in three district and session courts of Himachal Pradesh in North India, the following section describes such processes of production.

\section{Court setting and judiciary roles}

The ethnography of courthouses must take into consideration not only the courtroom, but also the institutional environment within which the courts operate. In India courtrooms are often located in a "judicial court complex," which also includes the Public Prosecutor's Office, the lawyers' compound, the office of the Superintendent of Police, and sometimes even the jail. Prosecutors are appointed by the government, but judges are more independent, working, however, under the supervision of higher courts. The judge's personality lends a courtroom its particular atmosphere: while some judges are rather passive listeners, others actively lead the discussions. The prosecutor's personality may also impact the way interactions unfold, but his or her role is less important than that of the judge. The legal representative of the legal party responsible for presenting the case in a trial against an individual suspected of breaking /p.359/ the law may actually be criticized by the judge - a reality that bestows on him or her a somewhat subordinate position vis-à-vis the court. Judges and lawyers also portray prosecutors, who basically work for the government, as less hard-working than judges, who are monitored by higher courts, and lawyers, who are paid by clients.

The spatial and physical disposition of people within the court is also relevant to the understanding of the ways in which power relations both influence and structure face-to-face relations throughout the trial. Trial courts are organized around the Session Judge's table: the reader who sets the sequence for the case, gives dates for the next hearing, and checks all files sits to the right, while the transcriber sits to the left. The prosecutor and defense attorneys stand in front of the judge but on a lower level, and witnesses appear behind a bar on both sides. During the examination, both the prosecutor and the defense attorneys may end up physically quite close to the witness, and even touch one another during the trial (assuming that both are men). Finally, assistants or junior lawyers accompany the defense lawyer, forming a sort of screen between the judge and the audience.

The result of this proximity is that interactions take place within a small group of people gathered together in front of the judge. Verbal interactions are often carried out at normal voice level, as in ordinary conversation, and are not always likely to be heard by those in attendance. In respect to the issue of audience, it should be noted that in Indian courts there is no jury, the jury system having been abolished in trial courts in 1960. The absence of a jury lessens the importance of performing the dialogues in ways that impress or emotionally affect a juror's opinion, allowing the judge, the prosecutor and the lawyers to discuss very technical points. The interactions regularly take the form of negotiations between the judge and the lawyers (and, in criminal cases, the prosecutor). The witnesses, especially when they are from rural areas and with little or no knowledge of English, are unable to follow negotiations of this kind, which constantly shift from the vernacular language to English and which often turn out to be rather animated discussions filled with interruptions. 
Unlike the witnesses, who are positioned close to the center of the action, the accused is kept to one side, often in a corner of the courtroom, and asked to remain standing and silent for the duration of the trial. Passive and muted throughout the proceedings, he or she is only heard at the very end of the trial, when asked by the judge or the reader to say something in his or her defense. Prior to that moment, the suspect's version of the facts emerges only and indirectly from the questions put to witnesses by the defense attorney.

\section{From oral interactions to written reports}

The pace of a trial is set by the speed with which the judge dictates the witness's words. After each question and reply sequence, the judge translates the sentence into English and repeats it to the transcriber. This leads us to consider the question of how witnesses' oral replies are transcribed and transformed into written court reports.

In this process of verbalizing oral interactions, I noticed that what is important is not so much the translation from the vernacular language into English, but the transformation of the oral question-reply into a written statement drafted in the first person. As an example, I now quote the opening dialogue between a judge and the mother of a woman who committed suicide in 2004. Two years later, the woman's /p.360/ husband was tried in Mandi District Court under section 306 of the Indian Penal code, "abetment of a woman to suicide."

Judge: Who was the victim to you?

Woman: She was my daughter.

Judge: How long had she been married for?

Woman: Eight to nine years.

The judge then translated the mother's answers into English in the form of a first-person sentence for the benefit of the transcriber whose job it is to record verbatim whatever is dictated to him: "Kamla deceased was my daughter, she was married to Guddu Ram about eight to nine years back in accordance with customary rites and ceremonies."

Standardized information not voiced by the witness (i.e. "in accordance with customary rites and ceremonies") is routinely added during this translation/transcription process. I observed that witnesses' replies are interpreted not only by the judge, but by the prosecutor and the defense attorney, who all compete to dictate the translation. This causes considerable friction between them, and this especially during cross-examinations, which make use of particularly "adversarial" and even "contradictory" techniques. What follows is an example of such techniques, which I draw from my documentation of a case involving a villager accused of cannabis cultivation. The dialogue quoted below centers around the main witness who now denies the police's report of his earlier testimony.

Judge: Is Narayan Singh [the accused] your cousin?

Witness: Yes, he's my cousin.

The judge dictates, "It's correct that Narayan Singh, the accused, is my cousin, my real cousin."

Judge: He is your cousin and that's why you are lying.

Witness: No, I'm not lying.

The judge translated this last sentence: "It is incorrect that I am deposing falsely because of my relation with the accused" (emphasis added).

The formula "it's correct" or "it's incorrect" allows any cross-examiner to ask so-called 
leading questions - that is, questions that can only be answered with "yes" or "no," and to add, at least in the English transcript, whatever he or she wants to add to the witness's statement. Of course, cross-examiners know that the witnesses will not corroborate their line of inquiry, but because they want their questions to appear in the final report, they ask them nonetheless. As one lawyer told me: "I still put the question because I've to keep a record of what my version is ..."

Consider the following exchange recorded during the trial of a man accused of having harassed his wife with dowry demands to the point that she took her life. During his cross-examination the defense lawyer tried to make the victim's mother say that at no point during the marriage had this man brought up the subject of money. As I quote:

\section{$/$ p.361/}

Lawyer: He [the accused] didn't ask for a dowry.

Mother: No!

The lawyer dictated to the transcriber: "It is incorrect that no demand of dowry was made at the time of my daughter's marriage" (emphasis added).

The confusing use of a double negation reappeared as the lawyer insinuated that dowry was not the cause of the woman's suicide:

Lawyer: Your daughter didn't commit suicide because of demands for dowry.

Witness: No!

The judge then dictates: "It is incorrect that my daughter had not committed suicide due to this reason."

Lawyers often play around with these formulas or they offer their own translations to judges or dictate them directly to transcribers. Another judicial technique, used by judges, consists in pronouncing, on behalf of the witness, a standardized formula whose effect is to implicitly suggest the contrary of what is explicitly said. For instance, once a judge expressed his conviction that the witness, the president of a panchayat, was lying in order to get the support of the accused in the upcoming panchayat elections. After the closing question, the judge dictated: "It is incorrect to suggest that I am deposing falsely in order to retain the accused as a loyal member of my panchayat."

During a trial, legal experts are very much focused on the transcription of the judiciary proceedings. But the production of this written report, the result of unquestioned codes of questioning and transcribing, runs parallel to the oral performance of the trial, whose own dynamics and interactions also need to be recorded by anthropologists of courtrooms, but only if they include the broader and cultural context that frames and often legitimizes a particular trial. It is to these considerations that we now turn.

\section{TOWARD AN ANTHROPOLOGY OF COURT CASES}

The different aspects of the trial technique that I have just described must be understood in order to approach law courts from another perspective - that is, as a lens through which we can observe developments of crucial import in India today. Here I have in mind such sociopolitical issues as the legal protection of "underprivileged" groups, environmental sustainability, narcotics control, and human rights, all of which are of crucial import in contemporary India. Now the state and various localities find themselves interacting in more or less antagonistic ways: as people feel that the state's claims violate or challenge their political-economic interests and their relationships with one another. As the next section 
evidences, the resultant conflicts or misunderstandings occasionally escalate into court cases.

\section{Criminal trials and out-of-court negotiations}

A set of issues closely associated with court activities, especially lower court activities, are those related to criminality - that is, to actions or practices that are punishable /p.362/ under the IPC (Indian penal code). One peculiarity of the IPC is that it has broadened the "crime" category to encompass a number of social discriminations. Over the last decades, a number of acts have been passed, often to consolidate erstwhile ineffective ones, which have officially criminalized practices and forms of relationships which were previously culturally approved (or simply suffered) as well as legally legitimated.4 One example is the Narcotic Drugs and Psychotropic Substances Act of 1985, which incorporates provisions designed to implement India's obligations under various international Conventions by criminalizing the cultivation of cannabis plants and opium, as well as the manufacture, transportation, and distribution of narcotic substances. Another example is section 113-A, introduced in 1983 into the Indian Evidence Act (1872), which establishes that if a married woman commits suicide within seven years of her marriage it may be presumed that her husband and his relatives subjected her to cruelty. Similarly, the Untouchability (Offences) Act (1955) and the Scheduled Castes and Scheduled Tribes (Prevention of Atrocities) Act (1989) introduce a criminalization of discrimination against these low status groups.

The police regularly register cases bearing on these acts. But people do not always accept the criminal nature of the practices regulated by these acts and they do not hesitate to contest the charge of wrongdoing. For reasons that cannot be explained here, even the people who initiate a legal case may change their minds later on and pursue non-official forms of compromise or adjustment. Ethnographic observations of the cases that do make it to the criminal courtroom thus provide insight into the kinds of tensions that arise between local society and the state judicial administration.

These tensions are particularly palpable when witnesses deny before the judge what they allegedly said to the police during preliminary investigations. At this very moment they often become hostile. Here I must point out that the problem of what in common law terminology is called "hostile witnesses" is, in fact, general in India and has provoked many a reaction from judges and politicians, as well as countless debates in newspaper editorials. Although this problem assumes particular relevance at high-profile, well-publicized trials, where witnesses may be politically pressured or bribed, it is a recurring everyday situation with which judges and prosecutors of any small district town are routinely faced. In many such cases, the hostile behavior results from various dynamics that interfere with the trial's outcome - village or family solidarity, the sharing of the same illegal activity for which the accused has been incriminated (as in case of cannabis cultivation), political interests, family pressures, various forms of economic compensation, and so forth. Sometimes the witness becomes "hostile" simply because police records of his or her earlier testimony are plainly wrong. Judges themselves are well aware that the police do write false statements for the purpose of strengthening their cases.

Though well known in judicial milieus, the dynamics just described have not yet been studied as they unfold over the course of a trial. My research suggests, however, that the witness's withdrawal from his or her previous statement is a crucial moment in the trial, one that clearly encapsulates the tensions arising between those involved in a trial and the court machinery itself. Examples of such difficult trials should further clarify this point. The first has to do with cannabis cultivation.

The cultivation of cannabis is a practice that was officially authorized throughout the colonial period but criminalized by the Indian state beginning in the 1960s, especially after introduction of the Narcotic Drugs Act quoted above. Villagers residing in /p.363/ areas 
where the cultivation of cannabis is still widespread actively contest this process of criminalization on grounds that cannabis plants were traditionally used in the performance of religious ceremonies, in medicine, and in some local dishes. This partly strategic, self-interested discourse turns, at times, into a more active, collective resistance. This was the case in the state of Himachal Pradesh when, in 2005, an entire village in Mandi district set up a barricade against a narcotic team from Chandigarh to prevent their cannabis crops from being destroyed. These people claimed that cannabis cultivation was under the jurisdiction of their village god and they went on to describe the police operation as an attack on their only source of livelihood (Tribune, July 26, 2005).

When a narcotic case is tried in a law court against a villager, the matter of the "cultural" or "ancestral" value of cannabis is never considered or even evoked by the witnesses or the defense lawyer. Witnesses called to testify against the accused instead try to obstruct the judiciary proceedings in order to prevent the prosecutor from proving his case. The reason for this behavior is that the witnesses summoned to testify are often from the same village and caste as the accused; they themselves may well cultivate cannabis in their own fields and therefore have a vested interest in blocking the prosecution. When they deny what they supposedly told the police, they are declared "hostile" and in court jargon accused of telling a lie "due to the relationship they have with the accused" (Berti, forthcoming b).

In some cases, it is not only co-villagers who are declared "hostile," but also land officers, local policemen and even the panchayat president. A prosecutor may start a trial with 15 or 20 witnesses and end up with no one to support the case. 5 Analysis of these proceedings both in and out of court sheds light on a very complex system of networks and alliances (family relations, cannabis connections, political ties with the panchayat's president, the local police or land officers, and so on), as well as a whole series of economic and social motivations. During a trial the judge may evoke this intricate and intensely politicized world by using the codified formulas previously described: "It is incorrect to suggest that I am deposing falsely in order to save the accused as a member of my panchayat."

In my fieldwork experiences, witnesses become "hostile" not only when they are directly implicated in a case filed by the police, but also when they are on the side of the plaintiff's party. During the often rather long period that elapses between the police investigation and the trial itself, I often observed, the party who has lodged the complaint (and who becomes the main witness) can irreparably compromise the case with the other party by means of compensation, threat or blackmail.

Out-of-court compromise interferes with the progress of the trial in various ways. One example is the case of a villager who was accused by his parents-in-law of having been so abusive to their daughter that she killed herself. The husband was tried at Mandi District Court in 2006 under section 306 of the IPC (abetment of a woman to commit suicide). At the time of the trial the victim's mother toned down her previous accusations, whispering to the judge that if her son-in-law was convicted there would be a problem with the children's custody. The judge did not make any comment then, nor did he order a court transcript of the woman's statement. At the end of the trial, the prosecutor characterized her (as well as the other witnesses) as hostile. Without a plaintiff and reliable evidence the judge had no choice but to acquit the husband6 (Berti, forthcoming a).

\section{/p.364/}

Another example is found in Pratiksha Baxi's study of rape cases in Gujarat (forthcoming) which shows how an out-of-court settlement may prevail in the courtroom when a compromise is made with the judge's complicity. The example Baxi gives concerns a love affair and sexual relationship between an upper caste girl and a low-caste boy. After they eloped, the girl's parents filed a case of rape and kidnapping. The boy was arrested and 
eventually the girl was married to a man of her caste. When the trial was held two years later, the girl's father found that an out-of-court compromise was the only way of preserving the daughter's new marriage. Without informing her husband, he took her to court so that she could testify that she never had any sexual relations with the accused or even met him for that matter. The judge declared the girl hostile but shortened the whole trial to one day by forgoing any cross-examination. No expert witnesses were summoned and the whole affair ended with the acquittal of the accused. Baxi points out that, contrary to the police records that provided very different versions of the girl's statement (sometimes making it sound like a love story and sometimes like a rape case), court transcriptions during the trial made no reference to this kind of compromise except as a residue - that is, by declaring the witness "hostile" (Baxi, forthcoming).

These examples suggest the different ways in which people organize themselves vis-à-vis the court once a judiciary process is underway. But my point here is that the "culture of compromise" (Baxi, forthcoming) described above can only be glimpsed through in-depth analyses of court proceedings and the multiple narratives and motivations that underlie them. This very ethnographic methodology has allowed Devika Bordia (2009) to examine how different forms of governance and justice circulate in everyday life, shape social relations, and contribute to the ethical self-fashioning of local leaders in the "tribal" regions of Western India. Her work on the relationship between the practices and politics of courts, police stations and panchayat leaders among the Bhil and Girassia of southern Udaipur shows how a criminal proceeding may be suspended even before it develops into a full-blown court case because of the multiple negotiations and underhand deals made between police officers, lawyers, magistrates, panchayat presidents, and other local leaders. Her recounting of the process by which a public autopsy was held supports her argument that both the court and the police "perpetuate the idea that tribal people are better governed through their own forms of panchayat and customary laws, constantly blurring the distinction between state law and non-state law" (Bordia 2009). The importance of studying the police as mediators between the local population and "competing organizations involved in governance" is also at the heart of Julia Eckert's study (2004) of the courts of Shiv Sena, a regional political party of the Hindu right, in Mumbai. Eckert points out that the police delegates the resolution of disputes to the local offices of this party and does not intervene in the illegal economic and political activities of Shiv Sena.

\section{Noncriminal judiciary cases and broader social issues}

Apart from the criminal matters just explored, court cases also provide unique access to litigation between state, nonstate, and international agencies. Some of these cases are usually (but not always) resolved at high courts and supreme courts and this is particularly the case of environmental lawsuits. Since the 1970s, the number of "environmental cases" filed at high courts throughout India has increased greatly, mostly due to the escalation and success of public interest litigations (PILs). Many /p.365/ environmental PILs are filed against local projects (dam constructions, hydroelectric projects, national parks, or tourist resorts) that are described as damaging to the environment and/or harmful to the local population. The court itself may initiate these lawsuits but any private party may do so as well - including local or international nongovernmental organizations (NGOs), civil activists, or politically or socially committed judges and lawyers.

On occasion, these various agencies clash with each other, as can been seen most vividly in Shalini Randeria's 2007 study of a controversy between environmentalists, WWF-India, and a human rights NGO over the conversion of an entire area of Rajasthan into a national park. The WWF environmentalists filed a case at the Supreme Court against the Government of India for failing to implement national environmental laws and policies. Their 
case against the creation of the park was aimed at the conservation of the lion population in Rajasthan (which, according to them, was by then an endangered species due to the traditional grazing methods used by rural communities, and for this reason these environmentalists called for the displacement of the local population). The human rights NGO, along with an action group set up to protect local people's customary rights of access to, and use of, natural resources, put forward a radically different argument. Over time environmentalists allied themselves with the regional government, defending the application of national legislation, while human rights activists found support in World Bank directives to guarantee the traditional rights of indigenous communities. Randeria used such PIL cases as a lens through which to study the interplay between the state, international institutions, and civil society, and their battle over different kinds of conflicting rights. Hers is not merely a study of courts, but also an ethnography of the state.7

Legal courts in India also process many cases having to do with religious issues, institutions and movements. These cases have often been addressed in relation to secularism; in fact the court is usually called upon to define the precise nature of and boundaries between Hinduism, Islam, Christianity, and the secular state. One of the first and most famous examples is the Bombay Court's decision in 1947 to allow untouchables to enter caste temples - a ruling that highlighted the role that secular states and institutions are called upon to play in ascertaining what is "religious" (Galanter 1971). In addition, the secular state in India is often involved in deciding what constitutes a "religious group" in the first place. This can be seen clearly in Ronojoy Sen's analysis of the Supreme Court's ruling that the Ramakrishna mission's petition be declared non-Hindu (Sen 2010) as well as in the many analyses of the so called "Hindutva Judgment," in which the Supreme Court decreed that Hinduism was a way of life and not a religion (Nauriya 1996; Noorani 2002).

Defining the boundary between the religious and the secular is only one aspect of the courts' intervention in the domain of religion. Another one has to with the right to inherit temple duties. The role of the court in this regard dates back to the British period, when the state took over the management of numerous major temples, becoming closely involved in supervising worship and daily rites, especially in the south (Presler 1987). British administrators provided temple deities with a "juristic personality," making it legal for them to be assigned land and property rights. Deities were thus legally defined as "minors" and their properties and rights were to be managed by temple administrators and staff (Sontheimer 1964; Annoussamy 1979). The multiple interests at work in temple management produced -

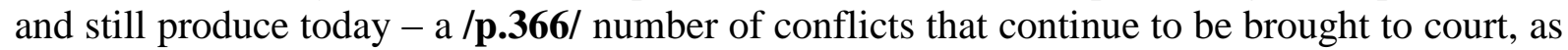
can be seen in the endless struggles over the ritual rules, honor privileges, and day-to-day administration of the Sabarimala temple and pilgrimage that have been fought over in the High Court of Kochi (Kerala, South India) for the past 50 years.

Environmental and religious issues are just two examples of the possible domains that may productively be explored through close analysis of noncriminal judiciary cases. Other issues onto which law courts shed light are those related to fundamental or constitutional rights - two concepts frequently used in India today, even among the rural population. Such cases are often heard at the Supreme Court, whose hierarchical structure and solemn ethos provide a stark contrast to the comparatively more informal and approachable lower courts. Here research should expand beyond court interactions or out-of-court negotiations to take into account the role played by the specific committee of experts convened by the court to provide specialist advice on the subject of litigation (Sood 2008:842). Moreover, Supreme Court activity also needs to be studied in its interaction with regional, national and international policies, since at this level of the judiciary court decisions may have direct effects on governance. 


\section{CONCLUDING REMARKS}

It is difficult to surmise where legal anthropology in India is currently headed. Nevertheless, certain developments are apparent. An important shift is the increasing attention paid to the study of court cases. This focus creates a common methodological framework by means of which issues related to political theory, law, and environmental or religious studies can be culturally contextualized. As I have tried to demonstrate in this chapter, a single court case can serve as a nexus at which to observe the interlocking of what are at times deeply antagonistic issues - as when the environmental question of endangered species in Gujarat is pitted against the right of protecting local people's access to natural resources. 8

Law cases, however, must be studied not only ethnographically, but also through a historical perspective that closely tracks their "judiciary (hi)stories." Such a two-pronged approach is necessary because many cases currently tried in Indian courts were opened years, even decades, ago. As such they require the study of documents provided to the courts or produced during the lawsuits as well as of the memories and multiple viewpoints of those involved in the cases - present-day plaintiffs (or their descendants), witnesses, and local people who remember them. This ethnohistorical approach highlights changes to which the case has been subjected over the decades, the successive types of judicial reasoning used in earlier arbitration, and the judiciary reforms that have developed over time. Moreover, judiciary reports and official documents recreate the "texture" by which the court and society have exchanged, formulated, negotiated or opposed conflicting opinions on a register that is "rule-oriented" (Conley and O'Barr 1990). And the ethnographic investigation of courts and the collection of narratives and practices outside of courts provide a more "relation-oriented" version of legal facts - a version expressed by the parties actually involved in the case, whose logic and points of view are deeply entrenched in social ties, economic interests, feelings, conflicts or loyalties.

\section{$/ p .367 /$}

The anthropology of court cases as proposed here presents a certain methodological specificity as compared to other anthropological topics. Indeed, its starting point is always a situation of conflict - whether that situation concerns a few individuals, whole families, or, as in the case of the PILs evoked above, an entire region, or even the country as a whole (as is the case when questions related to the constitution are under consideration). This makes it even more crucial for anthropologists to take into account the existence of multiple and opposite versions of the facts, some versions of which may be simply created by the parties for the sake of argument before the judge, while others may be defended by the parties both inside and outside the court.

What we have defined here as an anthropology of judiciary cases must not be taken as a separate discipline that is only of concern to anthropologists studying law, judicial proceedings, or legal settings. Though anthropologists have often perceived law courts in India as something alien to the layperson, it would be enough to spend just one day in a district court to realize not only how many people are actually involved, willingly or not, in such cases, but also how familiar some of them are with their legal rights and with judicial strategies of interaction more broadly. The kinds of experiences and discourses to which both urban and rural people are exposed during their involvement in such cases undoubtedly affect their ways of perceiving social or family relationships, and thus, in addition to all the other reasons already described, it is of increasingly crucial import that anthropologists working at the local level take legal practices and processes into fuller account. 


\section{NOTES}

1 See also Sylvia Vatuk (2005) for a study in a Muslim context.

2 Legal pluralism derives from the pioneering work of Sir Henry S. Maine, whose classic book Ancient Law (1861) catalogued numerous and diverse legal traditions in order to advance a grand theory of the development of law within a rigid evolutionary framework. Current interest in legal pluralism, however, draws from recent studies of postcolonial societies and their different normative orders.

3 At the village level there are various institutions by means of which disputes are discussed and arbitrated (Moore 1998). Among these are panchayat (councils), which may be related either to one caste (jati panchayat) or to the village (in the past, members of the dominant caste used to make up the village panchayat). On the comparison between panchayat and court proceedings, see Hayden 1984 and Moore 1998. In recent times, the state has sponsored Raj panchayat which cover a group of villages and whose president is periodically elected. These Raj panchayat deal more with local development and welfare than with dispute settlement.

4 The contrary is also true. Practices that used to be treated as crimes (for example homosexuality) have been decriminalized in a recent decision of the Delhi High Court.

5 The reader should note that in several criminal cases tried at the district level, the accused engages a defense lawyer who chooses not to present any defense witnesses.

6 Police reports are not conclusive evidence. In accordance with the rules of proceedings in force in India, only what a witness says before the judge can be taken as hard evidence. However, at the time of the trial, the judge, the prosecutor and the defense lawyer rely on these reports to formulate their questions.

7 In a very controversial book, Hans Dembowski (2001) scrutinized two major cases of environmental litigation in Kolkata. The volume provoked a strong reaction from the Court of Calcutta, which in 2001 began hearing a case of contempt against Dembowski and his publisher.

\section{/p.368/}

8 In some cases, the issues in question converge much more neatly - as, for example, when two PILs were recently filed simultaneously by environmentalists and the local population against the proposed Ford project to build a ski resort in Himachal Pradesh (Dogra 2006).

\section{REFERENCES}

Agnes, Flavia. 1999. Law and Gender Inequality: The Politics of Women's Rights in India. New Delhi: Oxford University Press.

Anderson, Michael R. 1990. Classifications and Coercions: Themes in South Asian Legal Studies in the 1980s. South Asia Research, 10(2):158-77.

Annoussamy, David. 1979. La Personnalité juridique de l'idole hindoue. Revue Historique de Droit Français et Étranger, 54(4):611-21.

Atkinson, John M., and Paul Drew. 1979. Order in Court: The Organization of Verbal Interaction in Judicial Settings. London: Macmillan.

Baxi, Pratiksha. Forthcoming [published 2011]. Justice is a Secret: Compromise in Rape Trials. Contributions to Indian Sociology [44(3), October 2010:207-233]

Baxi, Upendra. 1982. The Crisis of the Indian Legal System. New Delhi: Vikas.

Berti, Daniela. Forthcoming (a) [published 2011]. Hostile Witnesses: Judicial Interactions and Out of Court Narratives in a North Indian District Court. Contributions to Indian Sociology [44(3), October 2010:235-63]. 
Berti, Daniela. Forthcoming (b) [published 2011]. Trial, Witness and Local Stakes in a District Court of Himachal Pradesh (North India). In Citizenship, Democracy, and Belonging in the Himalayas. Johanna Pfaff-Czarnecka and Gérard Toffin, eds. Delhi: Sage (The Politics of Belonging in the Himalayas, pp.290-313].

Bordia, Devika. 2009. The Ethics and Politics of Governance in the Tribal Regions of Western India. $\mathrm{PhD}$ dissertation, Department of Anthropology, Yale University.

Chang, Yanrong. 2004. Courtroom Questioning as a Culturally Situated Persuasive Genre of Talk. Discourse and Society, 15(6):705-722.

Cohn, Bernard. 1987a. Anthropological Notes on Disputes and Law in India. In An Anthropologist among the Historians and Other Essays. Pp. 575-631. New Delhi: Oxford University Press.

Cohn, Bernard. 1987b. Some Notes on Law and Change in North India. In An Anthropologist among the Historians and Other Essays. Pp. 554-74 New Delhi: Oxford University Press.

Conley, John M., and William M. O'Barr. 1990. Rules versus Relationships. Chicago: University of Chicago Press.

Davis Donald, J. 2007. Hinduism as a Legal Tradition. Journal of the American Academy of Religion, 75(2):241-67.

Dembowski, Hans. 2001. Taking the State to Court: Public Interest Litigation and the Public Sphere in Metropolitan India. Oxford: Oxford University Press.

Derrett, J. Duncan M. 1957. Hindu Law Past and Present. Calcutta: A. Mukherjee.

Derrett, J. Duncan M. 1968. Religion, Law and the State in India. London: Faber and Faber.

Deva, Indra. 2005. Sociology of Law. New Delhi: Oxford University Press.

$/$. 369/

Dhagamwar, Vasudha. 2006. Role and Image of Law in India: The Tribal Experience. New Delhi: Sage.

Dogra, Chander Suta. 2006. Ford versus the Icons. Outlook, Feb. 6 : 48-9.

Drew, Paul, and John Heritage, eds. 1992. Talk at Work: Interactions in Institutional Settings. Cambridge: Cambridge University Press.

Dupret, Baudouin. 2006. Le Jugement en action. Ethnométhodologie du droit, de la morale et de la justice en Égypte. Geneva: Librairie Droz.

Eckert, Julia. 2004. Urban Governance and Emergent Forms of Legal Pluralism in Mumbai. Journal of Legal Pluralism, 50:29-60.

Freitag, Sandria B. 1991. Crime in the Social Order of Colonial North India. Modern Asian Studies, 25(2):227-61.

Galanter, Marc. 1968-9. Introduction: The Study of the Indian Legal Profession. Law and Society Review, 3(2-3) [Special issue on lawyers in developing societies with particular reference to India]:201-218.

Galanter, Marc. 1971. Hinduism, Secularism, and the Indian Judiciary. Philosophy East and West, 21(4):467-87.

Galanter, Marc. 1984. Competing Equalities: Law and the Backward Classes in India. Berkeley: University of California Press.

Galanter, Marc. 1992a[1989]. The Aborted Restoration of "Indigenous" Law in India. In Law and Society in Modern India. Rajeev Dhavan, ed. and introd. Pp. 37-53. Delhi: Oxford University Press. 
Galanter, Marc. 1992b. Law and Society in Modern India. Rajeev Dhavan, ed. and introd. Delhi: Oxford University Press.

Galanter, Marc, and Upendra Baxi. 1979. Panchayat Justice: An Indian Experiment in legal Access. In Access to Justice, vol. 3: Emerging Issues and Perspectives. Mauro Cappelletti and Bryant Garth, eds. pp. 341-86. Milan: Guiffre.

Galanter, Marc, and Dinesh Khosla. 1987. Myth and Reality of the Protection of Civil Rights Law: A Case of Untouchability in Rural India. Delhi: Hindustan.

Gnisci, Augusto, and Clotilde Pontecorvo. 2004. The Organization of Questions and Answers in the Thematic Phases of Hostile Examination: Turn-by-Turn Manipulation of Meaning. Journal of Pragmatics, 36: 965-95.

Hayden, Robert M. 1984. A Note on Caste Panchayats and Government Courts in India: Different Kinds of Stages for Different Kinds of Performances. Journal of Legal Pluralism, 22:43-52.

Holden, Livia. 2003. Custom and Law Practices in Central India: Some Case Studies. South Asia Research, 23:115-34.

Holden, Livia. 2008. Hindu Divorce: A Legal anthropology. Aldershot: Ashgate.

Kane, PandurangaVamana. 1950[1942]. Hindu Customs and Modern Law. Bombay: University of Bombay.

Lariviere, Richard W. 2005[1993]. A Persistent Disjunction: Parallel Realms of Law in India. In Religion and Law in Independent India. Robert D. Baird, ed. pp. 350-60. New Delhi: Manohar.

Larson, Gerald James, ed. 2001. Religion and Personal Law in Secular India: A Call to Judgment. Bloomington: Indiana University Press.

/p.370/

Lingat, Robert. 1973[1967]. Classical Laws of India. New Delhi: Oxford University Press.

Menski, Werner, ed. 1998. South Asians and the Dowry Problem. New Delhi: Vistaar.

Menski, Werner, ed. 2003. Hindu Law: Beyond Tradition and Modernity. Delhi: Oxford University Press.

Moore, Erin P. 1993. Gender, Power, and Legal Pluralism: Rajasthan. India. American Ethnologist 20(3):522-42.

Moore, Erin P. 1998. Gender, Law, and Resistance in India. Tucson: University of Arizona Press.

Mukhopadhyay, Anindita. 2006. Behind the Mask: The Cultural Definition of the Legal Subject in Colonial Bengal (1715-1911). Delhi: Oxford University Press.

Nauriya, Anil. 1996. The Hindutva Judgment: A Warning Signal. Economic and Political Weekly, 31(1):10-13.

Noorani, Abdul G. 2002. Citizens' Rights, Judges and State Accountability. New Delhi: Oxford University Press.

Presler, Franklin A. 1987. Religion under Bureaucracy: Policy and Administration for Hindu Temples in South India. Cambridge: Cambridge University Press.

Randeria, Shalini. 2007. The State of Globalization: Legal Plurality, Overlapping Sovereignties and Ambiguous Alliances between Civil Society and the Cunning State in India. Theory, Culture and Society, 24(1):1-33.

Richland, Justine B. 2008. Arguing with Tradition: The Language of Law in Hopi Tribal Court. Chicago: University of Chicago Press. 
Sathe, Satyaranjan P. 2002. Judicial Activism in India: Transgressing Borders and Enforcing Limits. New Delhi: Oxford University Press.

Sen, Ronojoy. 2010. The Indian Supreme Court and the Quest for a "Rational" Hinduism. South Asian History and Culture, 1(1):86-104.

Singha, Radhika. 1998. A Despotism of Law: Crime and Justice in Early Colonial India. New Delhi: Oxford University Press.

Sontheimer, Günther-Dientz. 1964. Religious Endowments in India: The Juristic Personality of Hindu Deities. Zeitschrift für Verglichende Rechts Wissenschaft, 87:44-100.

Sood, Avani Mehta. 2008. Gender Justice through Public Interest Litigation: Case Studies from India. Vanderbilt Journal of Transnational Law, 41:833-906.

Srinivas, M. N. 1964. A Study of Disputes. Delhi: University of Delhi.

Stiles, Erin E. 2009. An Islamic Court in Context: An Ethnographic Study of Judicial Reasoning. New York: Palgrave MacMillan.

Vatuk, Sylvia. 2005. Moving the Courts: Muslim Women and Personal Law. In The Diversity of Muslim Women's Lives in India. Zoya Hasan and Ritu Menon, eds. pp. 18-58. New Brunswick: Rutgers University Press. 